\section{Analisis Perbandingan Pembangunan Rumah Sederhana-Murah Kontruksi Panel EPS Dengan Kontruksi Konvensional}

\author{
Karel Soekma Jaya ${ }^{12}$ \\ ${ }^{1}$ Mahasiswa Program Studi Pendidikan Profesi Insinyur, \\ Universitas Lambung Mangkurat \\ 2Pengembang Perumahan PT Cipta Griya Sarana Asri, \\ Balikpapan
}

\section{karelsja@yahoo.co.id}

Tujuan Penelitian ini adalah untuk menganalisa apakah kontruksi dinding pracetak dalam hal ini Panel EPS lebih efisien dari segi waktu dan biaya jika dibandingkan dengan kontruksi konvensional. Pada penelitian ini, metode yang dilakukan adalah analisis perbandingan waktu dan biaya pada dinding rumah sederhana murah yang luas dan bentuknya sama terhadap kontruksi panel EPS dengan kontruksi konvensional. Penelitian ini difokuskan pada bangunan Rumah Sederhana Murah tipe 36 sebagaimana program pemerintah dalam mengatasi backlog perumahan. Dari penelitian ini diperoleh hasil bahwa secara keseluruhan biaya pekerjaan dinding pada rumah sederhana-murah yang menggunakan kontruksi panel EPS lebih murah dari segi biaya dan lebih cepat dari segi waktu pelaksanaanya dibandingkan dengan kontruksi konvensional

Kata kunci: Konvensional, Pracetak, Panel, EPS, Baja ringan, AHSP.

Diajukan: 29 Mei 2020

Direvisi: 4 Juni 2020

Diterima: 14 Juni 2020

Dipublikasikan online: 17 Juni 2020

\section{Pendahuluan}

Dinding adalah salah satu komponen elemen bangunan yang berfungsi memisahkan dan membentuk ruangan. Dinding juga berfungsi untuk memisahkan ruangan dengan lingkungan luar.

Sampai saat ini bata merah, batako atau bataringan (kontruksi konvensional) masih banyak digunakan sebagai dinding bangunan rumah tinggal dan bangunan gedung. Begitu juga dalam industri perumahan terkhusus untuk rumah sederhana murah, dengan kata lain masih jarang yang menggunakan dinding panel pracetak. Mitode pemasangan dinding dari bata konvensional harus diatur dan tersusun secara bertangga dan diperkuat oleh struktur kolom dan balok praktis setiap jarak maksimal 3 meter.

Seiring dengan kemajuan dan perkembangan teknologi konstruksi bangunan gedung yang semakin pesat, mulailah diciptakan kontruksi pracetak. Terdapat banyak variasi bahan atau material yang digunakan dan direkayasa sehingga menghasilkan produk kontruksi pracetak yang disesuaikan dengan kebutuhan. Salah satu inovasi dibidang kontruksi pracetak adalah dinding panel pracetak (panel precast). Produk panel pracetak dapat dipasang dengan cepat dan berkualitas, baik dari sisi struktur maupun dari sisi arsitektur.

Pada umumnya produk pracetak adalah untuk komponen-komponen yang berulang (repetitif), sehingga prosesnya cukup dibuat satu sebagai contoh, jika hasilnya memuaskan, maka akan dikerjakan yang lainnya dengan kualitas yang sama. Kontruksi seperti ini sering digunakan untuk proyek-proyek apartemen dan bangunan tinggi lainya, dengan alasan praktis dan lebih rapi. Adapun kontruksi panel pracetak yang akan kita bahas disini adalah panel EPS. Oleh karena itu, penelitian ini dilakukan untuk mengetahui apakah dinding rumah sederhana-murah konstruksi panel EPS lebih murah dibandingkan dengan konstruksi konvensional menggunakan Batako.

\section{Hipotesa}

Biaya untuk pekerjaan dinding konvensional (batako) lebih mahal dibanding dinding panel EPS. Waktu pelaksanaan pekerjaan dinding konvensional (batako) lebih lama dibanding dinding panel EPS.

\section{Metode}

Proyek adalah suatu kegiatan yang bersifat sementara yang dibatasi oleh jangka waktu tertentu, dibatasi alokasi sumber daya dan dibatasi oleh sumber pembiayaan, untuk tujuan dan hasil yang spesifik atau unik.

\section{Rumah Sederhana Murah}

Rumah Sederhana Murah adalah program pembangunan rumah yang diperuntukkan bagi MBR melalui program KPR subsidi Pemerintah. Yang harga maksimalnya telah ditentukan oleh Keputusan Menteri PUPR. Spesifikasi teknik kontruksi rumah murah tidak dibatasi oleh Pemerintah, kecuali tipe atau luasan bangunan wajib 36 meter persegi.

\section{Dinding Panel EPS}

Struktur panel EPS adalah terbuat dari tiga lapisan bahan atau material yang saling terikat secara presisi. Lapisan inti memiliki kepadatan rendah (polysterine) dan lapisan kulit memiliki kepadatan yang tinggi dan tipis. Kombinasi lapisan tersebut menghasilkan panel

Cara mensitasi artikel ini:

Jaya, K.S. (2020) Analisis Perbandingan Pembangunan Rumah Sederhana-Murah Konstruksi Panel EPS dengan Konstruksi Konvensional. Buletin Profesi Insinyur 3(1) 017-022 
komposit yang memiliki kekakuan struktural yang tinggi dan berbobot rendah. Keunggulan dari panel EPS adalah mereduksi panas, ringan, kuat, ramah lingkungan, permukaan halus, mudah dibentuk dan sangat aplikatif, sehingga penggunaan panel EPS ini mulai semakin diminati. Betuk dan spesifikasi panel EPS dapat dilihat pada Gambar 1.

\section{Dinding Konvensional}

Macam-macam kontruksi dinding yang dikerjakan dengan mitode konvensional antara lain pasangan bata merah, pasangan batako dan pasangan bata ringan. Dinding bata ringan memiliki bobot yang lebih ringan dibandingkan dengan bata merah dan batako. Namun harga bata ringan cukup mahal sehingga jarang digunakan untuk perumahan subsidi. Oleh karenanya kontruksi dinding konvensional yang digunakan pada penelitian ini adalah batako. Adapun dimensi batako yang banyak dipasaran Kota Balikpapan adalah tebal 75 $\mathrm{mm}$, tinggi $165 \mathrm{~mm}$ dan panjang $275 \mathrm{~mm}$.

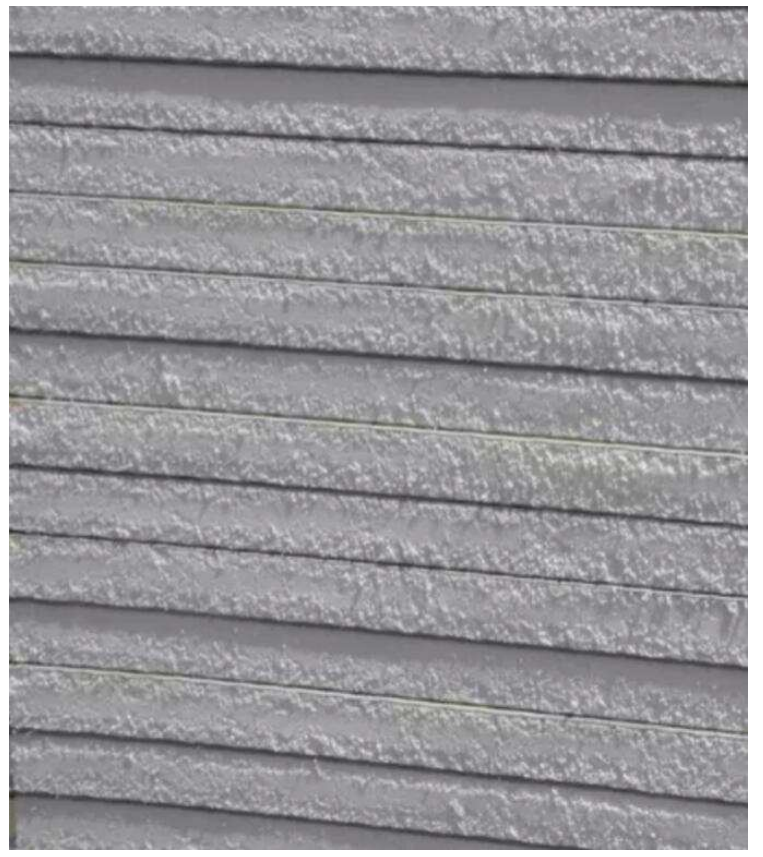

Gambar 1 Panel EPS $(75 \times 600 \times 3000) \mathrm{mm}$

\section{Anggaran Biaya Proyek Konstruksi}

Rencana Anggaran Biaya Proyek Kontruksi adalah perhitungan banyaknya biaya yang diperlukan untuk bahan dan upah kerja serta biaya- biaya lain yang berhubungan dengan pelaksanaan suatu proyek kontruksi. Anggaran biaya merupakan harga dari bahan bangunan dan upah kerja yang dihitung dengan teliti, cermat berdasarkan analisa harga satuan pekerjaan.

Analisa Harga Satuan Pekerjaan (AHSP-SNI) adalah alat yang digunakan untuk menghitung harga satuan pekerjaan konstruksi yang diterbitkan oleh instansi terkait di setiap Pemerintah Daerah di seluruh wilayah Indonesia.

Dalam hal ini penulis menggunakan analisa harga satuan pekerjaan (AHS) SNI Kota Balikpapan tahun 2018 untuk pekerjaan batako dan analisa harga satuan pekerjaan pemasangan dinding panel EPS menggunakan kondisi di lapangan.

\section{Waktu Pelaksanaan Proyek Konstruksi}

Time schedule adalah rencana alokasi waktu untuk menyelesaikan masing-masing item pekerjaan proyek, yang secara keseluruhan bisa disebutkan sebagai rentang waktu yang ditetapkan untuk melaksanakan suatu proyek kontruksi. Berdasarkan pengertian diatas bahwa schedule proyek merupakan waktu yang direncanakan untuk menyelesaikan proyek tersebut.

\section{Pertimbangan Teknis dan Batasan Masalah}

- Penelitian ini difokuskan pada bangunan Rumah Sederhana Murah tipe 36 sebagaimana program pemerintah dalam mengatasi backlog perumahan sebagai mana yang diatur dalam UU Nomor 1 Tahun 2011.

- Penelitian ini dikhususkan terhadap pekerjaan dinding pada bangunan rumah (Rumah Sederhana Murah).

- Struktur rumah yaitu sloof, kolom dan balok menggunakan bajaringan PRAKTIS U75.100 sebagaimana spesifikasi dalam Brosur Kolom Praktis Baja Ringan (PT. Tata Logam, 2016).

- Analisa Harga Satuan Pekerjaan dinding menggunakan Analisa Harga Satuan Pekerjaan AHSP) Kota Balikpapan tahun 2018 (Dinas PU Kota Balikpapan, 2018). Analisa harga satuan pekerjaan dinding panel EPS dihitung secara global, sehingga diperoleh harga satuan per-meter persegi.

- Analisa waktu pelaksanaan dinding panel EPS menggunakan asumsi kebutuhan tenaga perhari atau rata-rata nilai produktifitas pekerja perhari, berdasarkan analisa data pekerjaan dinding EPS. Analisa waktu pelaksanaan dinding konvensional (batako tanpa diplester) maupun dinding panel EPS menggunakan asumsi kebutuhan tenaga perhari atau rata-rata nilai produktifitas pekerja perhari, berdasarkan analisa data pekerjaan dinding batako tidak diplester.

- Pembahasan perhitungan hanya sebatas analisa biaya pekerjaan dinding dan tidak menghitung dari segi kekuatan struktur. Perhitungan harga sebatas material, upah kerja dan alat, tidak menghitung faktor resiko dan lansir material.

Sekalipun dalam penelitian ini tidak memperhitungkan kekuatan struktur dan kekuatan bahan, akan tetapi untuk menjamin bangunan rumah tersebut memenuhi ketentuan bangunan yang dipersyaratkan, maka struktur bajaringan dirancang mengikuti petunjuk yang diatur dalam Petunjuk Praktis Bangunan Domus (PT. Tatalogam Lestari, 2019). Dan produksi atau pembuatan panel EPS merujuk pada kekuatan yang setara dengan produk PT. Bakrie Building Industri sebagai mana tercantum dalam Katalog BBI Prefab Solution (PT. Bakrie Building Industri, 2019), dan produk-produk EPS buatan china. Yang mana panel EPS tersebut terdiri dari lapisan luar berupa viber semen yang dirancang menggunakan produk KalsiBoard atau produk Nusa Board perhatikan Katalog Produk KalsiBoard Jenis dan Spesifikasi (KalsiBoard, 2010) dan Jenis dan Spesifikasi Produk Nusa Board (Nusa Board, 2015), dan lapisan bagian dalam berupa polysterene yang memiliki density $16 \mathrm{Kg} / \mathrm{m}^{3}$ mengikuti standar yang berlaku di Inggris sebagaimana 
density yang disebutkan pada Technical Data Sheet, Page 42 (Izocam Manto Izopor, 2014) dan Technical Data Sheet for Expanded Polystyrene board for Alreflex Platinum (Thermal Economics Ltd, 2013). Serta direkatkan menggunakan tekanan memakai perekat Flexiboand (Dua Komponen Perekat Polyurethane Untuk Panel EPS Viber Kalsium Silikat (Beijing Comens New Materials Co. Ltd, 2018))

\section{Hasil Kerja}

Berdasarkan gambar rencana dinding suatu bangunan rumah, maka dapat dihitung jumlah volume luas dinding permeter persegi, sehingga dapat diketahui pula berapa banyak volume material-material yang akan dipakai atau digunakan.

Seperti hal dalam penelitian ini, dimana jumlah volume luas dinding permeter persegi dapat diketahui dengan menghitung jumlah luas dinding seperti pada Table 1 berdasarkan Gambar 2 dan Gambar 3.

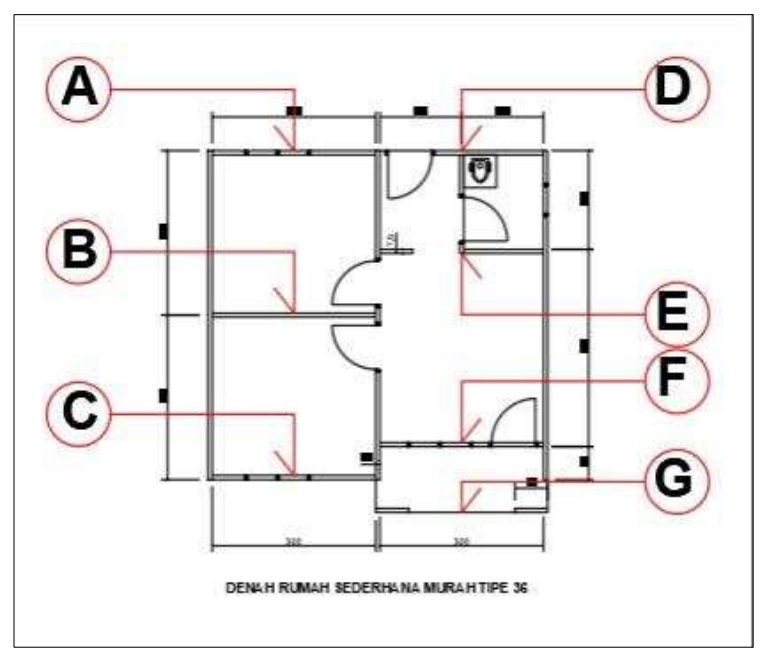

Gambar 2 Gambar Rencana Dinding A-G

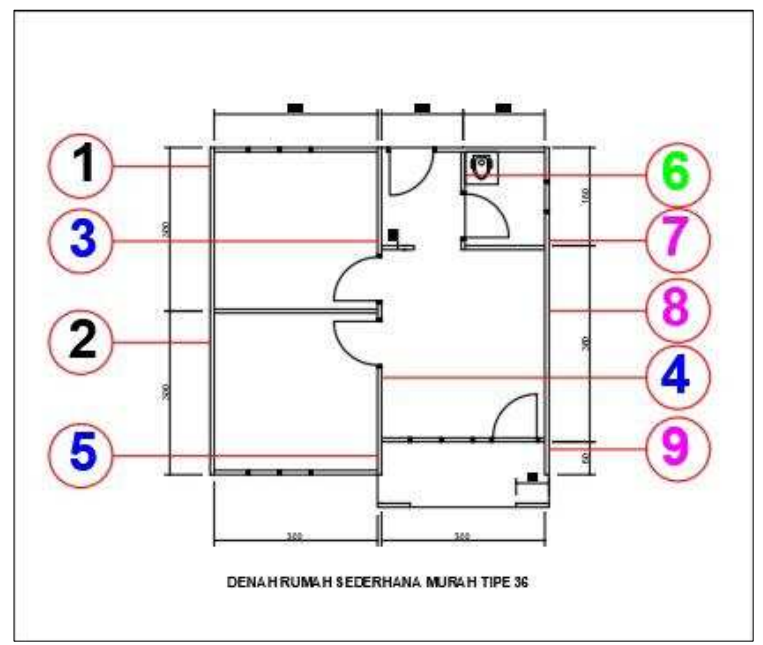

Gambar 3 Gambar Rencana Dinding 1-9

\section{Analisa}

\section{Perhitungan Biaya Pekerjaan Dinding Panel EPS}

Pada penelitian ini yang dimaksud dengan pekerjaan dinding panel EPS adalah rumah sederhana murah yang seluruh kontruksi dindingnya menggunakan panel EPS.

Dan selanjutnya untuk perhitungan biaya pekerjaan panel EPS seperti yang tercantum pada Tabel 4 merupakan penjumlahan biaya pabrikasi atau pembuatan panel EPS pada Tabel 2 dengan biaya pekerjaan pemasangan panel EPS pada Tabel 3.

Tabel 1 : Daftar volume Pekerjaan Dinding

\begin{tabular}{c|r|r|r|r|r|} 
No. Kode & $\begin{array}{c}\text { Lebar } \\
\text { M1 }\end{array}$ & $\begin{array}{c}\text { Tinggi } \\
\text { M1 }\end{array}$ & $\begin{array}{c}\text { Luas } \\
\text { M2 }\end{array}$ & $\begin{array}{c}\text { Opening } \\
\text { M2 }\end{array}$ & $\begin{array}{c}\text { L. bersih } \\
\text { M2 }\end{array}$ \\
\hline A & 3,00 & 3,00 & 9,00 & 2,04 & 6,96 \\
\hline B & 3,00 & 3,00 & 9,00 & - & 9,00 \\
\hline C & 3,00 & 3,00 & 9,00 & 2,04 & 6,96 \\
\hline D & 3,00 & 3,00 & 9,00 & 2,25 & 6,75 \\
\hline E & 3,00 & 3,00 & 9,00 & 2,70 & 6,30 \\
\hline F & 3,00 & 3,00 & 9,00 & 4,29 & 4,71 \\
\hline G & 3,00 & 3,00 & 9,00 & 4,95 & 4,05 \\
\hline 1 & 3,00 & 3,00 & 9,00 & - & 9,00 \\
\hline 2 & 3,00 & 3,00 & 9,00 & - & 9,00 \\
\hline 3 & 3,00 & 3,00 & 9,00 & 1,80 & 7,20 \\
\hline 4 & 2,40 & 3,00 & 7,20 & 1,80 & 5,40 \\
\hline 5 & 0,60 & 3,00 & 1,80 & - & 1,80 \\
\hline 6 & 1,80 & 3,00 & 5,40 & 1,80 & 3,60 \\
\hline 7 & 1,80 & 3,00 & 5,40 & 0,30 & 5,10 \\
\hline 8 & 3,60 & 3,00 & 10,80 & - & 10,80 \\
\hline 9 & 0,60 & 3,00 & 1,80 & - & 1,80 \\
\hline & & & Jumlah Luas Dinding & 98,43 \\
\hline
\end{tabular}

Tabel 2 Harga Satuan Pekerjaan Pabrikasi Panel EPS

\begin{tabular}{|c|c|c|c|c|}
\hline Uraian Kebutuhan & Sat. & Koefisien & H. Satuan & Jum. Harga \\
\hline \multicolumn{5}{|l|}{ Bahan } \\
\hline Viber semen & Lbr & 1,000 & 127.200 & 127.200 \\
\hline Styrofoam & M3 & 0,113 & 975.000 & 110.565 \\
\hline Perekat & $\mathrm{Kg}$ & 0,540 & 42.500 & 22.950 \\
\hline Reng bajaringan & Btg & 1,000 & 32.750 & 32.750 \\
\hline \multicolumn{5}{|l|}{ Upah } \\
\hline Pekerja & Org & 0,048 & 125.000 & 5.952 \\
\hline \multirow[t]{5}{*}{ Mandor } & Org & 0,002 & 200.000 & 476 \\
\hline & & & Jumlah & 299.894 \\
\hline & & \multicolumn{2}{|c|}{ Overhead $10 \%$} & 29.989 \\
\hline & & \multicolumn{2}{|c|}{ HSP } & 329.883 \\
\hline & $\mathrm{HSPPe}$ & nbuatan $1 \mathrm{n}$ & 12 Panel EPS & 183.268 \\
\hline
\end{tabular}

Tabel 3 Harga Satuan Pekerjaan Pemasangan Panel EPS

\begin{tabular}{|c|c|c|c|c|}
\hline Uraian Kebutuhan & Sat. & Koefisien & H. Satuan & Jum. Harga \\
\hline \multicolumn{5}{|l|}{ Bahan } \\
\hline Panel EPS & Lbr & 1,000 & 329.883 & 329.883 \\
\hline Sekrup & Buah & 3,000 & 645 & 1.935 \\
\hline Dempul & $\mathrm{Kg}$ & 0,040 & 12.500 & 500 \\
\hline \multicolumn{5}{|l|}{ Alat } \\
\hline Bor listrik & Hari & 0,040 & 1.100 & 44 \\
\hline Mesin listrik & Hari & 0,040 & 4.225 & 169 \\
\hline \multicolumn{5}{|l|}{ Upah } \\
\hline Pekerja & Org & 0,110 & 125.000 & 13.750 \\
\hline Tukang batu & Org & 0,011 & 175.000 & 1.925 \\
\hline Mandor & Org & 0,001 & 200.000 & 220 \\
\hline \multirow{2}{*}{\multicolumn{4}{|c|}{$\begin{array}{r}\text { Jumlah } \\
\text { Overhead 10\% }\end{array}$}} & 348.426 \\
\hline & & & & 34.843 \\
\hline \multicolumn{4}{|c|}{ HSP } & 383.269 \\
\hline \multicolumn{4}{|c|}{ HSP Pemasangan $1 \mathrm{M} 2$ Panel EPS } & 212.927 \\
\hline
\end{tabular}




\section{Perhitungan Biaya Pekerjaan Dinding Batako}

Pada penelitian ini yang dimaksud dengan pekerjaan dinding Batako adalah rumah sederhana murah yang seluruh kontruksi dindingnya menggunakan pasangan batako yang tidak diplester dan tidak diaci, kecuali pada dinding teras dan dinding depan sebelah luar saja.

Tabel 4 Hasil Perhitungan Total Biaya Pekerjaan Dinding Panel EPS

\begin{tabular}{r|r|r|r|r|} 
No. Kode & $\begin{array}{c}\text { Luas } \\
\text { M2 }\end{array}$ & $\begin{array}{c}\text { HPS Per-M2 } \\
\text { Panel EPS }\end{array}$ & $\begin{array}{c}\text { HPS Per-M2 } \\
\text { Lain-lain }\end{array}$ & \multicolumn{1}{c|}{$\begin{array}{l}\text { Jumlah } \\
\text { Harga }\end{array}$} \\
\hline A & 6,96 & 212.927 & - & 1.481 .972 \\
\hline B & 9,00 & 212.927 & - & 1.916 .343 \\
\hline C & 6,96 & 212.927 & - & 1.481 .972 \\
\hline D & 6,75 & 212.927 & - & 1.437 .257 \\
\hline E & 6,30 & 212.927 & - & 1.341 .440 \\
\hline F & 4,71 & 212.927 & - & 1.002 .886 \\
\hline G & 4,05 & 212.927 & - & 862.354 \\
\hline 1 & 9,00 & 212.927 & - & 1.916 .343 \\
\hline 2 & 9,00 & 212.927 & - & 1.916 .343 \\
\hline 3 & 7,20 & 212.927 & - & 1.533 .074 \\
\hline 4 & 5,40 & 212.927 & - & 1.149 .806 \\
\hline 5 & 1,80 & 212.927 & - & 383.269 \\
\hline 6 & 3,60 & 212.927 & - & 766.537 \\
\hline 7 & 5,10 & 212.927 & - & 1.085 .928 \\
\hline 8 & 10,80 & 212.927 & - & 2.299 .612 \\
\hline 9 & 1,80 & 212.927 & - & 383.269 \\
\hline & & & & 20.958 .405 \\
\hline
\end{tabular}

Tabel 5 Harga Satuan Pekerjaan Pasangan batako

\begin{tabular}{l|l|r|r|r|}
$\begin{array}{l}\text { Uraian Kebutuhan } \\
\text { Bahan }\end{array}$ & Sat. & Koefisien & H. Satuan & Jum. Harga \\
\hline Batako & Buah & 20,000 & 3.750 & 75.000 \\
\hline Pasir pasang & M3 & 0,045 & 370.000 & 16.650 \\
\hline Semen portland & $\mathrm{Kg}$ & 9,680 & 1.900 & 18.392 \\
\hline Angkur & Ls & 1,000 & 15.000 & 15.000 \\
\hline $\begin{array}{l}\text { Upah } \\
\text { Pekerja }\end{array}$ & & & & \\
\hline Organg batu & Org & 0,300 & 125.000 & 37.500 \\
\hline Kepala tukang & Org & 0,100 & 150.000 & 15.000 \\
\hline Mandor & Org & 0,015 & 175.000 & 1.750 \\
\hline & & & 200.000 & 3.000 \\
\hline & & & Jumlah & 182.292 \\
\hline & & & Overhead 10\% & 18.229 \\
\hline
\end{tabular}

Tabel 6 Harga Satuan Pekerjaan Plesteran dan Acian

\begin{tabular}{l|l|r|r|r|}
\hline $\begin{array}{l}\text { Uraian Kebutuhan } \\
\text { Bahan }\end{array}$ & Sat. & Koefisien & H. Satuan & Jum. Harga \\
\hline Pasir pasang & M3 & 0,026 & 370.000 & 9.620 \\
\hline Semen portland & $\mathrm{Kg}$ & 5,184 & 1.900 & 9.850 \\
\hline Kawat ram ayam & $\mathrm{LS}$ & 1,000 & 15.000 & 15.000 \\
\hline $\begin{array}{l}\text { Semen untuk acian } \\
\text { Upah }\end{array}$ & $\mathrm{Kg}$ & 3,250 & 1.900 & 6.175 \\
\hline $\begin{array}{l}\text { Pekerja } \\
\text { Tukang batu }\end{array}$ & Org & 0,350 & 125.000 & 43.750 \\
\hline Kepala tukang & Org & 0,250 & 150.000 & 37.500 \\
\hline Org & 0,025 & 175.000 & 4.375 \\
\hline Org & 0,018 & 200.000 & 3.500 \\
\hline & Org & Jumlah & 129.770 \\
\hline & & Overhead 10\% & 12.977 \\
\hline
\end{tabular}

Selanjutnya perhitungan biaya pekerjaan dinding batako merupakan penjumlahan biaya pekerjaan pasangan batako dengan biaya pekerjaan plesteran dan acian sebagaimana dijelaskan dalam Tabel 5, Tabel 6 dan Tabel 7.

Pada dinding $\mathrm{C}$ dan $\mathrm{F}$ yang menggunakan kontruksi pasangan batako yang diplester dan diaci pada sisi sebelah luarnya dan pada dinding $\mathrm{G}$ diplester dan diaci di kedua sisinya, sehingga secara keseluruhan menambah komponen pekerjaan yang berakibat pada biaya yang lebih mahal $7,10 \%$ dari biaya pekerjaan dinding panel EPS.

Tabel 7 : Hasil Perhitungan Total Biaya Pekerjaan Dinding Batako diplester dan diaci

\begin{tabular}{r|r|r|r|r|} 
No. Kode & $\begin{array}{c}\text { Luas } \\
\text { M2 }\end{array}$ & $\begin{array}{r}\text { HPS Per-M2 } \\
\text { Pas. Batako }\end{array}$ & $\begin{array}{c}\text { HPS Per-M2 } \\
\text { Plesteran }\end{array}$ & $\begin{array}{c}\text { Jumlah } \\
\text { Harga }\end{array}$ \\
\hline A & 6,96 & 200.521 & - & 1.395 .628 \\
\hline B & 9,00 & 200.521 & - & 1.804 .691 \\
\hline C & 6,96 & 200.521 & 142.747 & 2.389 .144 \\
\hline D & 6,75 & 200.521 & - & 1.353 .518 \\
\hline E & 6,30 & 200.521 & - & 1.263 .284 \\
\hline F & 4,71 & 200.521 & 142.747 & 1.616 .791 \\
\hline G & 4,05 & 200.521 & 285.493 & 1.968 .358 \\
\hline 1 & 9,00 & 200.521 & - & 1.804 .691 \\
\hline 2 & 9,00 & 200.521 & - & 1.804 .691 \\
\hline 3 & 7,20 & 200.521 & - & 1.443 .753 \\
\hline 4 & 5,40 & 200.521 & - & 1.082 .814 \\
\hline 5 & 1,80 & 200.521 & - & 360.938 \\
\hline 6 & 3,60 & 200.521 & - & 721.876 \\
\hline 7 & 5,10 & 200.521 & - & 1.022 .658 \\
\hline 8 & 10,80 & 200.521 & - & 2.165 .629 \\
\hline 9 & 1,80 & 200.521 & - & 360.938 \\
\hline & & & & 22.559 .401 \\
\hline
\end{tabular}

\section{Perbandingan Dan Selisih Biaya Kontruksi}

Dari Tabel 8 dan Gambar 4 dapat dilihat dengan jelas bahwa biaya pekerjaan dinding menggunakan kontruksi panel EPS lebih mahal $5,8 \%$ dari biaya yang menggunakan kontruksi konvensional, kecuali untuk dinding $\mathrm{C}, \mathrm{F}$ dan $\mathrm{G}$.

Tabel 8 Perbandingan Dan Selisih Biaya Kontruksi

\begin{tabular}{|r|r|r|r|r|r|}
\hline No. Kode & \multicolumn{1}{|c|}{$\begin{array}{c}\text { Luas } \\
\text { M2 }\end{array}$} & $\begin{array}{r}\text { HPS Per-M2 } \\
\text { Panel EPS }\end{array}$ & $\begin{array}{r}\text { HPS Per-M2 } \\
\text { Konvesional }\end{array}$ & \multicolumn{1}{c}{$\begin{array}{c}\text { Selisi } \\
\text { Biaya }\end{array}$} & \multicolumn{1}{c|}{$\begin{array}{c}\text { Prosen } \\
\text { tase }\end{array}$} \\
\hline A & 6,96 & 1.481 .972 & 1.395 .628 & 86.344 & $5,83 \%$ \\
\hline B & 9,00 & 1.916 .343 & 1.804 .691 & 111.652 & $5,83 \%$ \\
\hline C & 6,96 & 1.481 .972 & 2.389 .144 & 907.172 & $-61,21 \%$ \\
\hline D & 6,75 & 1.437 .257 & 1.353 .518 & 83.739 & $5,83 \%$ \\
\hline E & 6,30 & 1.341 .440 & 1.263 .284 & 78.157 & $5,83 \%$ \\
\hline F & 4,71 & 1.002 .886 & 1.616 .791 & 613.905 & $-61,21 \%$ \\
\hline G & 4,05 & 862.354 & 1.968 .358 & 1.106 .004 & $-128,25 \%$ \\
\hline 1 & 9,00 & 1.916 .343 & 1.804 .691 & 111.652 & $5,83 \%$ \\
\hline 2 & 9,00 & 1.916 .343 & 1.804 .691 & 111.652 & $5,83 \%$ \\
\hline 3 & 7,20 & 1.533 .074 & 1.443 .753 & 89.322 & $5,83 \%$ \\
\hline 4 & 5,40 & 1.149 .806 & 1.082 .814 & 66.991 & $5,83 \%$ \\
\hline 5 & 1,80 & 383.269 & 360.938 & 22.330 & $5,83 \%$ \\
\hline 6 & 3,60 & 766.537 & 721.876 & 44.661 & $5,83 \%$ \\
\hline 7 & 5,10 & 1.085 .928 & 1.022 .658 & 63.270 & $5,83 \%$ \\
\hline 8 & 10,80 & 2.299 .612 & 2.165 .629 & 133.983 & $5,83 \%$ \\
\hline 9 & 1,80 & 383.269 & 360.938 & 22.330 & $5,83 \%$ \\
\hline & & & & & \\
\hline
\end{tabular}

\section{Perbandingan Waktu Dan Biaya Sewa Scaffolding}

Karena dalam penelitian ini hanya membahas tentang perbandingan bangunan rumah sederhana murah tipe 36, yang menggunakan spesifikasi teknik yang sama, kecuali pada kontruksi dinding, maka alat bantu yang digunakan adalah sama, yaitu scaffolding.

Adapun jumlah escafolding yang digunakan dalam pelaksanaan pekerjaan dinding pada rumah sederhana murah tipe 36 ini adalah sebanyak 2 unit. Yang mana pemakaian atau sewa scaffolding untuk pekerjaan dinding Panel EPS memerlukan waktu selama 3 hari. Sementara untuk pemakaian atau sewa scaffolding pada pekerjaan dinding batako memerlukan waktu 


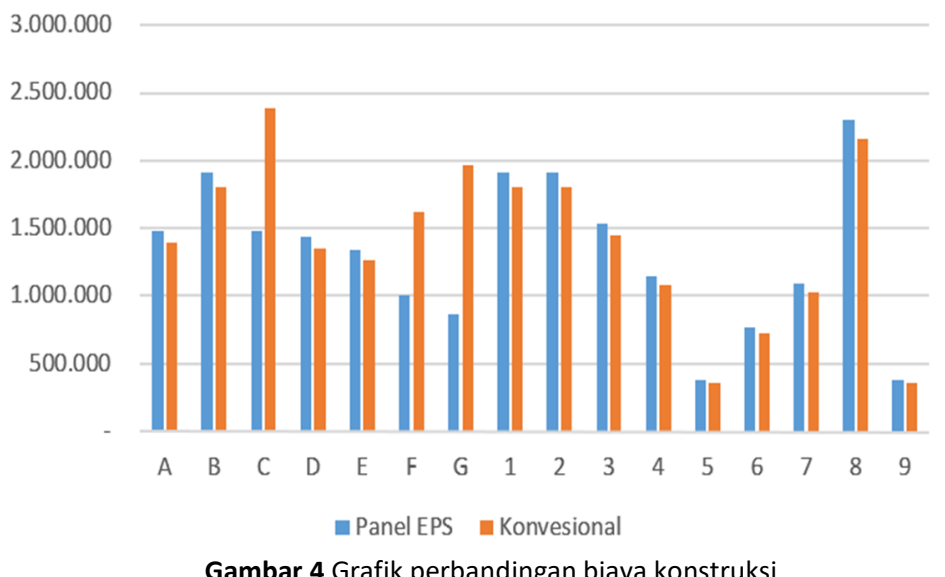

selama 11 hari. Sehingga terdapat selisih jumlah hari pemakaian atau sewa yaitu selama 8 hari.Ini berarti pula terdapat selisih harga sewa scaffolding, yaitu sebesar 8 hari dikali harga sewa scaffolding perhari.

\section{Perbandingan Waktu Pelaksanaan Pekerjaan Dinding Panel EPS Dengan Dinding Batako}

1. Waktu yang diperlukan untuk mengerjakan dinding panel EPS, yaitu sebagai berikut :

Dihitung berdasarkan kemampuan rata-rata hasil pabrikasi atau pembuatan panel ESP yang dicapai dalam 1 hari kerja (effektif 7 Jam perhari), dalam hal ini diperoleh 36 Lembar panel EPS atau $64,8 \mathrm{~m}^{2}$. Sehingga pabrikasi atau pembuatan dinding panel EPS untuk keperluan 1 unit rumah sederhana murah tipe 36 atau 98,43 $\mathrm{m}^{2}$ dibutuhkan waktu 1,5 hari. Sementara untuk proses pengeringan panel membutuhkan waktu 1 hari.

Dan waktu yang diperlukan untuk melaksanakan pekerjaan pemasangan panel EPS dalam 1 hari kerja adalah 19 Lembar atau $34 \mathrm{~m}^{2}$ panel EPS. Sehingga untuk melaksanakan pekerjaan pemasangan dinding panel EPS 1 unit rumah sederhana murah tipe 36 atau 98,43 $\mathrm{m}^{2}$ adalah 3 hari.

Pada Gambar 5 jelas tergambar jumlah waktu yang dibutuhkan dalam pelaksaan pekerjaan dinding panel EPS adalah 4,7 hari, namun untuk waktu pekerjaan persiapan, pabrikasi dan pengeringan panel EPS dapat diabaikan karena dapat dikerjakan pada saat bangunan rumah sederhana murah tipe 36 ini mulai dilaksanakan, sehingga dapat dikatakan bahwa waktu yang dibutuhkan untuk pekerjaan dinding panel EPS pada bangunan rumah sederhana murah tipe 36 adalah 3 hari.

2. Waktu yang diperlukan untuk mengerjakan dinding batako, yaitu sebagai berikut :

Pekerjaan dinding batako dilaksanakan dalam 3 tahap. Tahap Pertama adalah pekerjaan pasangan batako. Tahap Kedua adalah pekerjaan plesteran dinding. Tahap Ketiga adalah pekerjaan acian dinding.

Adapun kemampuan untuk melaksanakan pekerjaan pasangan batako dalam 1 hari kerja adalah seluas $9,84 \mathrm{~m}^{2}$. Sehingga waktu yang dibutuhkan untuk melaksanakan pekerjaan pasangan batako 1 unit rumah sederhana murah tipe 36 atau $98,43 \mathrm{~m}^{2}$ adalah 10 hari.

Sementara waktu yang dibutuhkan untuk melaksanakan pekerjaan plesteran seluas $19,77 \mathrm{~m}^{2}$ adalah 1,11 hari.

Dan waktu yang dibutuhkan untuk melaksanakan pekerjaan acian seluas $19,77 \mathrm{~m}^{2}$ adalah $3,89 \mathrm{Jam}$

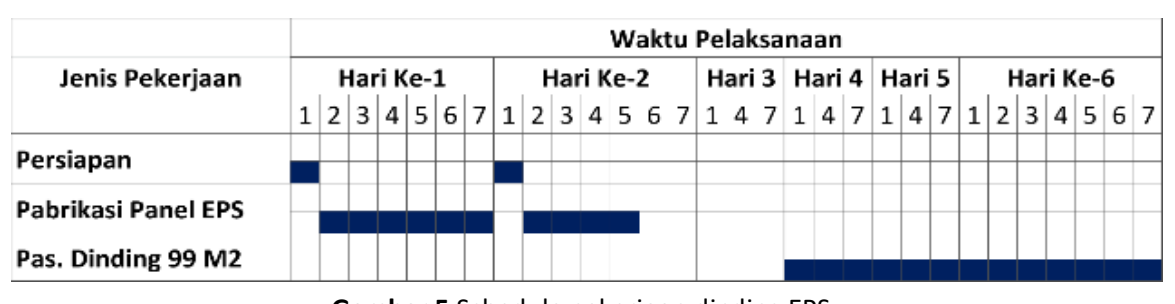

Gambar 5 Schedule pekerjaan dinding EPS

\begin{tabular}{|c|c|c|c|c|c|c|c|c|c|c|c|c|c|c|c|c|c|}
\hline \multirow{3}{*}{ Jenis Pekerjaan } & \multicolumn{17}{|c|}{ Waktu Pelaksanaan } \\
\hline & \multicolumn{6}{|c|}{ Hari Ke-1 s.d. Ke-9 } & & Hari Ke-10 & \multicolumn{4}{|c|}{ Hari Ke-11 } & \multicolumn{5}{|c|}{ Hari Ke-12 } \\
\hline & 12 & 23 & 4 & 56 & 7 & 8 & & 1234567 & 123 & & 56 & & 1 & 23 & & & 67 \\
\hline Pas. Dinding 99 M2 & & & & & & & & & & & & & & & & & \\
\hline Plesteran & & & & & & & & & & & & & & & & & \\
\hline Acian & & & & & & & & & & & & & & & & & \\
\hline
\end{tabular}

Gambar 6 Schedule pekerjaan dinding batako 
Dimana luasan bidang dinding yang diplester dan diaci adalah $19,77 \mathrm{~m}^{2}$ yang merupakan bidang dinding $\mathrm{C}, \mathrm{F}$ dan $\mathrm{G}$ pada 1 unit rumah sederhana murah tipa 36.

Pada Gambar 6 dapat dilihat dengan jelas bahwa jumlah waktu yang diperlukan untuk melaksanakan pekerjaan dinding batako 1 unit rumah sederhana murah tipe 36 adalah 11,4 hari.

3. Perbandingan waktu dalam melaksanakan pekerjaan dinding panel EPS dengan dinding batako pada 1 unit rumah sederhana murah tipe 36, yaitu sebagai berikut :

Pada Gambar 7 terlihat dengan jelas, bahwa pelaksanaan pekerjaan dinding panel EPS dikerjakan lebih cepat 8,4 hari dibandingan dengan pelaksanaan pekerjaan dinding batako.

Dimana waktu pelaksanaan pekerjaan persiapan, pabrikasi dan pengeringan panel EPS diabaikan, karena pekerjaan tersebut dilaksanakan bersamaan dengan pelaksanaan pekerjaan lainnya pada saat pembangunan rumah sederhana murah tipe 36 dimulai.

Sehingga pekerjaan dinding panel EPS diselesaikan dalam waktu 3 hari. Sementara pekerjaan dinding batako membutuhkan 11,4 hari (akumulasi pekerjaan pasangan batako, plesteran dan acian).

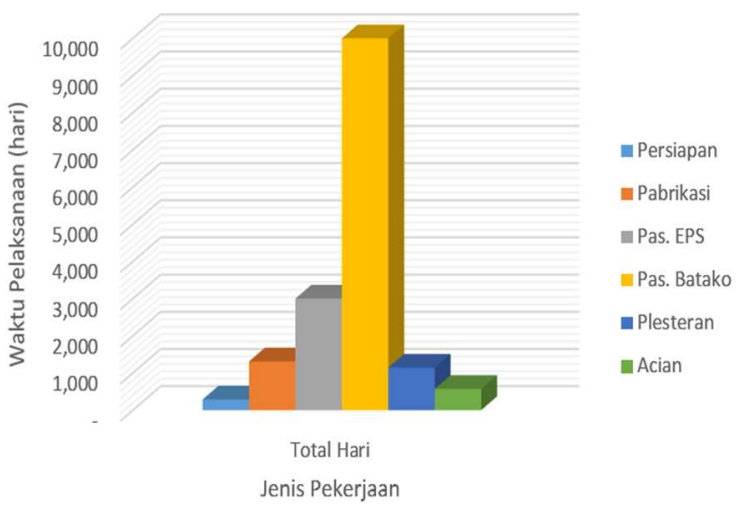

Gambar 7 Perbandingan Waktu Pelaksanaan Pekerjaan Dinding Panel ESP Dengan Dinding Batako

\section{Kesimpulan}

Dari hasil analisis, beberapa hal yang dapat disimpulkan antara lain:

1. Pembangunan rumah sederhana murah yang pekerjaan dindingnya menggunakan kontruksi Panel ESP lebih mahal 5,8 \% dari kontruksi pasangan batako yang tidak diplester dan diaci.

2. Pembangunan rumah sederhana murah yang pekerjaan dindingnya menggunakan kontruksi pasangan batako yang diplester dan diaci hanya pada sebagian dindingnya (dinding depan di sisi depan serta dinding teras dikedua sisinya) lebih mahal 7,10\% dari kontruksi panel EPS.

3. Penggunaan panel EPS menghasilkan dinding yang kedap suara, tahap api, anti rayap dan permukaannya rata dan rapi, sehingga dapat langsung dilakukan pekerjaan pengecetan.
4. Penggunaan pasangan batako yang tidak diplester dan diaci ataupun yang dipleser dan diaci sebagian, tidak dapat langsung dilakukan pekerjaan pengecatan karena masih memerlukan pekerjaan plesteran dan acian. Sangat diharapkan sebelum dihuni terlebih dahulu diplester dan diaci.

5. Waktu yang diperlukan untuk mengerjakan dinding rumah sederhana murah dari kontruksi panel EPS adalah 3 hari.

6. Waktu yang diperlukam untuk mengerjakan dinding rumah sederhana murah dari kontruksi batako yang diplester dan diaci pada sebagian dindingnya adalah 11,4 hari.

7. Waktu pelaksanaan pekerjaan dinding panel EPS lebih cepat 8,4 hari dari pekerjaan dinding batako.

8. Untuk menunjang pekerjaan ini diperlukan 2 unit scafolding, yang mana terdapat selisih waktu pemakaian 8,4 muhari, sehingga biaya pemakaian atau sewa scafolding untuk pekerjaan pemasangan batako lebih mahal 8,4 hari di kali biaya sewa scafolding.

9. Secara keseluruhan biaya pekerjaan dinding pada rumah sederhana murah yang menggunakan kontruksi panel EPS lebih murah dan lebih cepat pelaksanaanya dibandingkan dengan kontruksi konvensional.

\section{Ucapan Terima kasih}

Ucapan terima kasih penulis kepada Program Profesi Insinyur, Fakultas Teknik Sipil Universitas Lambung Mangkurat yang telah memfasilitasi penulis dalam mempublikasikan Buletin ini.

\section{Referensi}

Undang-undang Republik Indonesia Nomor 1 Tahun 2011 Tentang Perumahan dan Kawasan Permukiman. 2012. Jakarta: Biro Hukum dan Kepegawaian Kementerian Perumahan Rakyat.

PT. Tatalogam Lestari. 2019. Petunjuk Praktis Bangunan Domus. Jakarta: PT. TataLogam Lestari.

Dinas PU Kota Balikpapan. 2018. Analisa Harga Satuan Pekerjaan SNI Kota Balikpapan Tahun 2018. Balikpapan: Dinas PU Kota Balikpapan.

Mukomoko, J. A. 2007. Dasar Penyusunan Anggaran Biaya Bangunan. Jakarta: Gaya Media Pratama.

Irika Widiasanti \& Lenggogeni. 2013. Manajemen Konstruksi. Bandung: Remaja Rosdakarya.

KalsiBoard. 2010. Katalog Produk KalsiBoard Jenis dan Spesifikasi. Jakarta: KalsiBoard.

Nusa Board. 2015. Jenis dan Spesifikasi Produk Nusa Board. Jakarta: Nusa Board.

Thermal Economics Ltd. 2013. Technical Data Sheet for Expanded Polystyrene board for Alreflex Platinum. Luton: Thermal Economics Ltd.

Izocam Manto Izopor. 2014. Technical Data Sheet, Page 42, diunduh dari http://www.Izocam.com.tr pada Agustus 2019.

Beijing Comens New Materials Co. Ltd. 2018. Dua Komponen Perekat Polyurethane Untuk Panel EPS Viber Kalsium Silikat. Guangdong: Alibaba.com.

PT. Bakrie Building Industri. 2019. Katalog BBI Prefab Solution. Jakarta : PT. Bakrie Building Industri. 